Article

\title{
Questioning Low-Carbon Transition Governance: A Comparative Analysis of European Case Studies
}

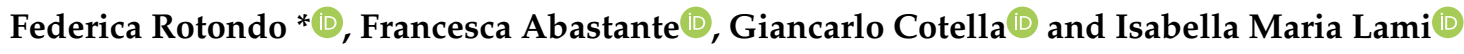 \\ Interuniversity Department of Regional and Urban Studies and Planning (DIST), Politecnico di Torino, \\ Viale Mattioli, 39, 10125 Turin, Italy; francesca.abastante@polito.it (F.A.); giancarlo.cotella@polito.it (G.C.); \\ isabella.lami@polito.it (I.M.L.) \\ * Correspondence: federica.rotondo@polito.it
}

Received: 7 October 2020; Accepted: 4 December 2020; Published: 14 December 2020

\begin{abstract}
To achieve the international emission reduction targets, current researches underline the need to overcome the dominant techno-centric approaches to energy transition, in favor of analyses that explore in more detail those practices and organizational assets that play a role in favoring a transition towards a low-carbon society. In this light, the article focuses on governance practices and, in particular, on the different tools and actors involved across variable scales and temporalities. Drawing on the activities of the ERASMUS+ Strategic Partnership for Higher Education LOTUS (Locally Organized Transition of Urban Sustainable Spaces), a selection of European case studies is explored and compared in light of (i) the implemented actions in terms of energy production and efficiency measures, (ii) the legal framework and the origin of the funding and (iii) the number and type of involved actors and their partnerships. On this basis, the analysis outlines, from both a theoretical and a practical stand, a number of critical issues that characterize these episodes of energy transition governance. In particular, the authors reflect upon the interaction between energy measures and urban contexts, the need for synergies among government level and the emergence of new forms of partnership among public, private and third parties' actors.
\end{abstract}

Keywords: energy transition; governance; low-carbon society; comparative studies; Europe

\section{Introduction}

The European Union (EU) has been developing policies aiming at more sustainable use of energy resources for almost two decades [1]. In 2009, the European Commission set ambitious objectives aiming at reducing by $20 \% \mathrm{CO}_{2}$ emissions and increasing by $20 \%$ energy efficiency and renewable energy production in comparison to 1990 levels [2]. Five years later, as part of the European Green Deal, the European Council defined the targets for 2030, aiming at a reduction of at least $40 \%$ of greenhouse gas (GHG) emissions, the achievement of at least 32\% of energy dependence on renewable sources and an increase of at least 32.5\% of energy efficiency [3]. Finally, in November 2018, the Commission put forward a long-term vision for reducing $\mathrm{CO}_{2}$ for a climate-neutral EU by 2050 and launched its "2050 long-term strategy" to guide European countries towards a low-carbon economy, in line with energy security, environmental and economic goals [4].

Accounting for more than 70\% of global GHG emissions from final energy use, cities are required to play a pivotal role in implementing the strategy, and have been progressively defining governing arrangements and policies aiming at energy transition and, more in general, paving the way towards a low-carbon society [5,6]. However, many cities are failing to achieve reductions in GHG emissions, and a gap emerges between local public policy program and actual practices and interventions [7-9]. As argued by [10], this gap between policy and practice can be related to three main factors: (i) the local history of engagement with environmental issues, (ii) the lack of competencies and (iii) the scarce 
availability of financial resources. In this direction, numerous contributions already underlined the need to adopt a more holistic approach and to consider the decarbonization of cities as a complex transition, where energy efficiency measures and technologies for energy conservation are conceived not just as "engineered artefacts" but also as social configurations which have emerged contingently in particular contexts [11-15]. In other terms, there is a growing agreement on the important role that human energy could play in the picture $[11,16]$ and that "sustainability objectives cannot be achieved with technical fixes alone but necessitate a more fundamental transformation of both structural and societal systems" [17] (pag.13).

In more detail, a number of authors have been recently arguing in favor of the transformation of socio-economic systems, including new forms of social relations and governance dynamics, and the need to consider issues of institutional capacity and factors of political economy $[8,16]$. This mirrors a renovated attention to public policy and governance arrangements (rules, guidelines, etc.), the acknowledgement of the various agencies, their power and preferences, the recognition of the social and political constellations that characterize the urban contexts at stake $[7,16,18]$. In other words, it calls for higher attention to the immateriality of low-carbon transition, the roles and relations of the involved actors (such as planners and policymakers), the mix of public and private interests and the tools that are more likely to produce an impact when implemented through a specific actors' constellation $[7,18,19]$.

Acknowledging these debates, the present contribution proposes to shift the focus of the analysis on current governance practices and, in particular, on the different tools and actors involved across the variable scales and temporalities that characterize the low-carbon transition in a given context. In doing so, the authors draw on the activities of the ERASMUS+ Strategic Partnership for Higher Education LOTUS (Locally Organized Transition of Urban Sustainable Spaces. Further details available in [20]), to explore a selection of European case studies and to compare them in light of three main research questions:

(i) What are the implemented actions in terms of energy production and efficiency measures?

(ii) What are the legal framework and the origin of the funding within which the experiences develop?

(iii) What are the number and type of the involved actors and what partnerships link them?

After this introduction, the context of the research is further sketched out through a brief literature review that focuses on recent studies on the low-carbon transition, its meaning and its characteristics. Section 3 presents the main approach and methodology of the research, then Section 4 details the selection criteria and the case studies that are investigated in the subsequent paragraphs. Section 5 presents the results of the case studies' analysis in relation to the three interpretative lenses defined by the research questions above. Finally, a concluding section rounds off the contribution, presenting the authors' final considerations on the outcomes of the study and its limitations, and introducing a number of avenues for future research on the matter. Overall, the proposed analysis highlights that, if cities have to make a step forward in the transition towards a low-carbon society, more concrete synergies between the different government levels are to be developed and better-suited forms of partnership among public, private and third parties' actors identified.

\section{Setting the Context}

The attention of the academic environment in relation to a transition towards a low-carbon society is rather recent, and its roots can be retraced in the overall debate surrounding the emergence of the sustainable development paradigm that emerged starting from the end of the 1980s [21]. When it comes to the specific urban connotation of the debate, two generations of studies are identifiable, dealing with urban low-carbon transition, that span from the late 1990s until nowadays $[7,8]$ and that have been accompanied by related urban policy development strands in Europe and beyond [22-24].

The first generation of studies places particular emphasis on the technological and economic dimensions and on the need for a radical shift in this specific domain [11]. These contributions are 
based on an "extractive" model of low-carbon transition that gives attention to the techno-economic innovation in substitution of carbon-based systems and practices, and increases the efficiency of the way we use carbon. They tend to adopt Socio-Technical Transition (STT) and Multi-level Perspective (MLP) approaches as epistemic and conceptual frameworks for understanding and advancing in the transition [25-27]. According to SST and MLP, transitions are non-linear processes shaped by interplay niches, intended as the locus for radical innovations, socio-technical regimes of established practices and rules, and exogenous technical landscape. The dynamics and changing interactions among these three analytical levels determine various pathways towards the transition, passing through the stability of existing regimes and changes [28]. Critiques to these approaches mainly refer to the underestimation of agency and power relations in the transition, the overlook of the national scale at the expense of local and regional agencies, the lack of consideration for peculiar urban conditions and the disregarding of any path-dependent logic from a historical perspective [28].

More recently, acknowledging these critical elements, a second generation of studies started to highlight the need to consider the transition not just as a technical, infrastructural or systemic issue, but also as inherently characterized by, and dependent from, a social dimension; in other words, arguing in favor of devoting further attention to social variables, governance models and mechanisms, spatial contexts, agency and power [8]. Moving in this direction, an increasing number of authors progressively enlarged the scope of their research activity, in so doing proposing to reposition the low-carbon transition of cities as a development process, underlying the role played by its inherent political, geographical and development implications [28]. According to this position, each transition is a contingent and politically contested process that implies a multiplicity of systems, agents and scales that relate to each other and give rise to the reconfiguration of social interest, political arrangement and technology $[7,28]$. This second generation of studies thus shifts to an "embedded" model of low-carbon transition that considers specific political rationalities, geographical contexts and development pathways as fundamental aspects to be problematized [7]. In particular, some authors underline the need for alternative perspectives and call for further research on the issues of agency's dynamics, politics and power and material infrastructure by adopting approaches that look at local governance practices "on the ground" $[8,16]$.

The present contribution positions itself within this second strand of researches, which shifts the attention from the achievement of a specific set of more or less technical objectives to the investigation of experiences of low-carbon transition, to be analyzed and discussed in relation to the respective geographical, socioeconomic and institutional contexts, governance models and implementation tools [23]. In this light, a particularly important role in influencing the characteristics of each case is played by the territorial governance and spatial planning traditions that characterize each place, by their administrative and regulatory frameworks, as well as by the dynamics of action and interaction among the subjects involved in implementing low-carbon transition measures [29-31].

\section{Materials and Methods}

This section illustrates the methodology adopted in the present study, by focusing on (i) the research project that frames our contribution, (ii) the conceptual lenses adopted in the investigation and (iii) the methodological approach followed in the case study analysis and comparison.

This paper discusses a number of European experiences, selected in the framework of the Erasmus+ project LOTUS, whose aim is to design higher education tools to inspire Europe's future city planners, architects and administrative staff to guide communities towards a greener future and to transfer successful concepts across borders and national contexts [32,33]. With the aim of testing and implementing new energy concepts in a dynamic framework, a city planning serious game (Serious Game Urban Energy Management UrbEM-Game) is currently under development on the basis of a catalogue of real-world scenarios (Catalogue of Real Cases-CoRC) [34], that will contribute to testing and validating the serious game mechanism [35] in relation to their understanding of the emerging practices in energy governance and the peculiar dynamics that link the involved 
actors in different regulatory and institutional contexts. In more detail, to explore possible paths towards the reduction of GHG emissions, the LOTUS partners built a shared database of case studies ranging from two main areas of intervention: the renewable energy sources area, aimed at lowering emissions on the supply side, and the energy conservation area, whose aim is the increase in energy efficiency on the demand side [36]. On the demand side, projects led by local authorities were included, such as housing renovation schedules, subsidies to drilling energy performance (insulation, solar panels) new eco-friendly districts, energy-saving educational schemes for dwellers, public transport, environmentally friendly transportation, regulations (individual parking space, traffic), planning and zoning. On the supply side, we considered projects that imply the cooperation between private or private/public actors, e.g., heat origination from industry to be used for urban heating and/or electricity production, geothermal energy need land, electricity or heat production from biomass, mechanization from agriculture residues and wind turbines on farming land.

Our contribution is framed under the lenses of policy analysis and network governance in understanding the constitutive nature of infrastructural arrangements and social practice in the low-carbon transition of cities [37]. Governing low-carbon transition in the cities is a multi-actor and multiscale process that involves a variety of agents (ranging from the private sector to politicians, academia and the civil society), that interact at different scales (from that of the single dwelling to the national and transnational one) and governance levels (municipalities, national organization, European agencies) [38,39]. In this light, investigating low-carbon transition calls for a specific focus on the role that the different actors play, as well as the logics they mobilize in the specific context of their interests and in relation with the local urban agenda [38,40]. Within this framework, the present paper focuses on those interventions concerning energy production and energy-saving in various urban contexts that were collected and analyzed by the authors in the context of the CoRC.

To investigate the case studies, the LOTUS partners jointly adopted a qualitative comparative approach [41], that consists of an analytical grid allowing for direct comparison among cases studies in relation to a series of features (institutional, strategic, socioeconomic and technical). The present contribution thus employs a "context sensitive" approach that allows the analysis of a limited number of case studies [39] in light of the following selected elements: (i) the origin of the funding and the legal framework in which the experiences are included, (ii) the number and type of involved actors and partnerships among them and (iii) the characteristics and typologies of interventions concerning the production of clean energy and energy saving. The adoption of an analytical grid is particularly useful in exploring and comparing the case studies in the view of the specific research questions of this work [42,43]. Moreover, the grid allows a double level of analysis and data interpretation: from the one side, it allows to look for "explicit connections" among the selected cases, to ensure a certain degree of generalization and, ultimately, to push for further investigation; from the other side, it opens opportunities for further investigations in relation to each case, in so doing allowing for a deeper understanding of the relations between the investigated phenomena and the peculiar aspects of the administrative, regulative and governance framework within which they occur [29,31,41].

Further details motivating the selection of these cases and introducing their geographical location and the type of interventions put in practice, are presented in the section below.

\section{Introduction to the Case Studies}

The empirical ground of the present contribution has been structured into three main steps: (i) the identification of suitable case studies, (ii) the selection of the 10 case studies to be analyzed and (iii) the collection of data.

The identification of suitable case studies has been derived from existing databases, defined and built in the framework of two European research projects aiming at supporting professionals and local authorities in low-carbon transition at the local level in the European context. The two European Projects are EU FP MILESECURE-2050 (2013-2015: Multidimensional Impact of the Low-carbon European Strategy on Energy Security) [44], to which some of the authors of the present paper took active 
part, and SMARTEES (2018-2021: Social Innovation Modelling Approaches to Realizing Transition Energy Efficiency and Sustainability) [45], whose information was retrieved from the project final reports. Altogether, the aforementioned databases include over 100 projects considered as exemplary or anticipatory experiences in energy planning practices at the local level $[46,47]$. In particular, their anticipatory character resides in the fact that they anticipate at the local level some basic features of a low-carbon society, and present important elements of innovation in relation to the governance models in place, the instruments adopted, and the ways of engagement of different public and private actors.

The selection of the 10 case studies to be analyzed has been based on the general principle that they should be interesting not only from the perspective of the results achieved, but also according to the decision and policy-making processes that had characterized them $[48,49]$. Furthermore, the case studies were selected to allow for an extensive coverage of different geographical and institutional contexts, territorial scales and issues related to energy and planning as energy renovation of buildings, new constructions, integration of energy production in an urban development project, reduction of energy consumption by urban transport. In more detail, three main criteria have been adopted in the selection: (i) the cases should concern issues related not only to the energy and environmental spheres, but integrate also economic, social and governance aspects; (ii) they all should be completed or well advanced and start from the assumption of aiming at sustainable and energy-saving targets in local urban realities, in technological, organizational and social terms; and (iii) they should include a plurality of individual and collective actors (in term of interests, resources and knowledge) who belong to the public and/or private arena, including owners, managers, users, agencies, local organizations and others.

The collection of data consisted in the analysis of plans, financial statements, schedules and programs that were retrieved from the EU FP MILESECURE-2050 and SMARTEES official reports [46,47], integrated through additional desk research and updated with key information available on the respective municipal websites including video, case presentation leaflet, reports and planning documents.

In Table 1, the selected case studies are listed according to their timeframe and main objectives. For the sake of simplicity, an acronym listed in the last column of the table has been assigned to each case study. As shown in Table 1, the selected experiences affect a timeframe that ranges between 1994 (NL) and $2025(\mathrm{CH})$. There are different situations when it comes to launching, conducting and concluding the case studies: the case of FR covers a short-term period (up to 5 years); NL, FR, ES2, $\mathrm{SE}, \mathrm{CH}$, DK cover a medium-term period (from 10 to 15 years); ES1, DE, UK, IT cover instead a longer period (more than 15 years) as they are part of long-term development visions. This evidence contributes reinforcing the idea that the implementation of energy-saving and clean energy production interventions is generally expected to take place in the medium-long term. As showed in Figure 1, the selected case studies are located in nine different European countries: Spain and Italy in the southern side (ES1, IT, ES2); France, Switzerland, Germany and the Netherlands in the central part of Europe (FR, CH, DE, NL); the United Kingdom, Denmark and Sweden in the northern part (UK, FR, SE, DK). They are rather heterogeneous in relation to the main issues they deal with, but also in relation to the territorial context they focus on and the type(s) of tool they adopt (Figure 2). In more detail, most cases concern projects (NL, FR, SE, ES1) and local initiatives (DE, IT, UK, DK), the largest share of which is located in central and northern Europe, and only a minority of cases adopts instead sectoral plans (ES2) and programs (CH) related to energy. For the sake of simplicity, in the following text we will refer to "experiences" or "cases" as terms that include sectoral plans, projects, programs and initiatives. Moreover, the selected cases range from the district scale (NL, FR, SE) to the village scale (DE, IT), and up to the scale of a medium-sized city (ES2, CH) or a county (UK). The selected cases also include two island contexts at the opposite ends of Europe along the southwest-northeast diagonal (respectively ES1, DK). The main issues addressed by the case studies are (i) reduction of GHG emissions related to the urban transport system (ES2, CH), (ii) energy renovation of existing in urban contexts (NL, SE), (iii) new construction of energy buildings (FR), (iv) new construction of 
clean energy production systems (DE, UK, IT) and (v) energy self-sufficiency (ES1, DK). This thematic heterogeneity will be further taken into account in the following section.

Table 1. The 10 cases study and their main features (Source: authors' own elaboration).

\begin{tabular}{|c|c|c|c|}
\hline Case Study's Name & Timeframe & Main Objectives & Acronym \\
\hline $\begin{array}{l}\text { Sustainable Järva district } \\
\text { regeneration } \\
\text { (Stockholm, Sweden) }\end{array}$ & 2007-2014 & $\begin{array}{l}\text { Reaching the targets of the city to } \\
\text { become fossil free by } 2050 \text {. } \\
\text { The main aim for Järva district is } \\
\text { to become a model of } \\
\text { sustainability, promoting } \\
\text { environmental responsibility and } \\
\text { energy efficiency while still } \\
\text { preserving its cultural and } \\
\text { historical values }\end{array}$ & SE \\
\hline $\begin{array}{l}\text { Island Renaissance } \\
\text { (Samsø, Denmark) }\end{array}$ & 1997-2007 & $\begin{array}{l}\text { Achieving "energy independence" } \\
\text { in the island thanks to the } \\
\text { combination of renewable energy } \\
\text { production and energy efficiency } \\
\text { measures }\end{array}$ & DK \\
\hline $\begin{array}{l}\text { Baywind energy community } \\
\text { (Cumbria, UK) }\end{array}$ & from 1996 & $\begin{array}{l}\text { Living within a fair share of the } \\
\text { earth's resources }\end{array}$ & UK \\
\hline $\begin{array}{l}\text { Eva Lanxmeer } \\
\text { (Culemborg, The Netherlands) }\end{array}$ & 1994-2009 & $\begin{array}{l}\text { Promoting a sustainable and } \\
\text { environmental-friendly } \\
\text { development by being an example } \\
\text { of integrated approach towards } \\
\text { sustainable planning }\end{array}$ & NL \\
\hline $\begin{array}{l}\text { Bio Energy Village } \\
\text { (Jühnde, Germany) }\end{array}$ & From 2006 & $\begin{array}{l}\text { Substituting all fossil fuels for } \\
\text { electricity and heat production } \\
\text { with biomass }\end{array}$ & $\mathrm{DE}$ \\
\hline $\begin{array}{l}\text { Renaissance/EU Concerto } \\
\text { (Lyon, France) }\end{array}$ & 2005-2010 & $\begin{array}{l}\text { Constructing a new "green } \\
\text { district" in the city center targeting } \\
\text { exemplary construction in terms } \\
\text { of energy efficiency and the use of } \\
\text { renewable energy. It is part of an } \\
\text { ambitious city-center urban } \\
\text { regeneration project in Confluence }\end{array}$ & FR \\
\hline $\begin{array}{l}\text { Urban Traffic } \\
\text { Programme/Stadtverkehr } 2025 \\
\text { (Zurich, Switzerland) }\end{array}$ & 2012-2025 & $\begin{array}{l}\text { Increasing } 10 \% \text { in public transport, } \\
\text { pedestrian and bicycle traffic in } \\
\text { overall traffic until } 2025\end{array}$ & $\mathrm{CH}$ \\
\hline $\begin{array}{l}\text { Sistema Peccioli } \\
\text { (Peccioli, Italy) }\end{array}$ & from 1997 & $\begin{array}{l}\text { Facing an environmental issue of } \\
\text { the village related to a poorly } \\
\text { managed refuse dump, collecting } \\
\text { waste from five municipalities }\end{array}$ & IT \\
\hline $\begin{array}{l}\text { El Herrio. } \\
\text { (Spain) }\end{array}$ & From 1999 & $\begin{array}{l}\text { Gaining resilience and autonomy } \\
\text { in energy supply to become a } \\
\text { sustainable island substituting } \\
\text { fossil fuel-based by renewable } \\
\text { energy sources }\end{array}$ & ES1 \\
\hline $\begin{array}{l}\text { Urban Mobility Plan with } \\
\text { Superblocks } \\
\text { (Vitoria Gasteiz, Spain) }\end{array}$ & 2010-2023 & $\begin{array}{l}\text { Providing a holistic solution to } \\
\text { urban planning needs, traffic } \\
\text { planning and other citizens' needs } \\
\text { and deals with issues relating to } \\
\text { the availability and quality of } \\
\text { transport, emissions and quality } \\
\text { of air, the use of public space, } \\
\text { noise pollution and } \\
\text { energy consumptions }\end{array}$ & ES2 \\
\hline
\end{tabular}




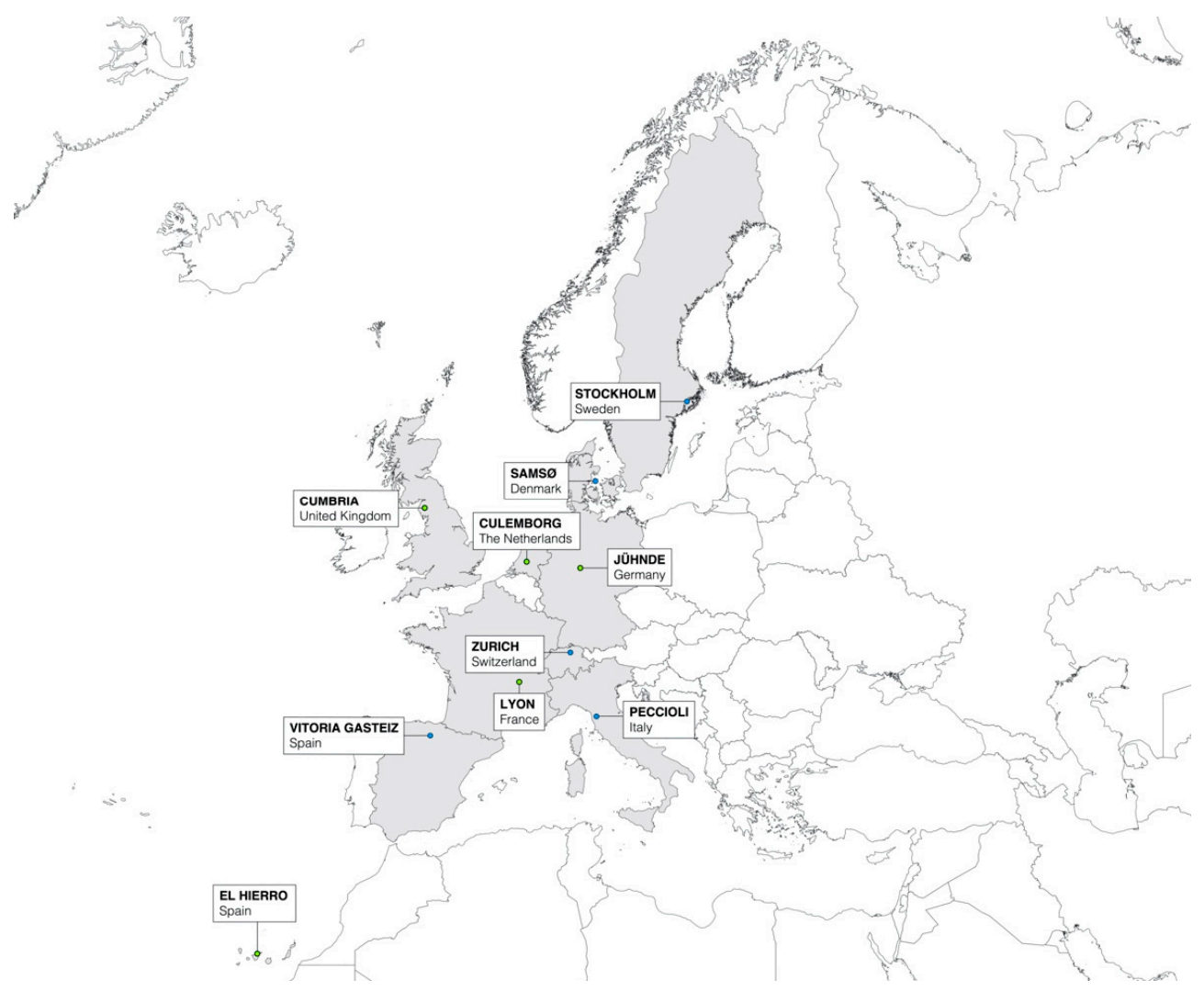

Figure 1. Geographical distribution of the case studies (source: authors' own elaboration).

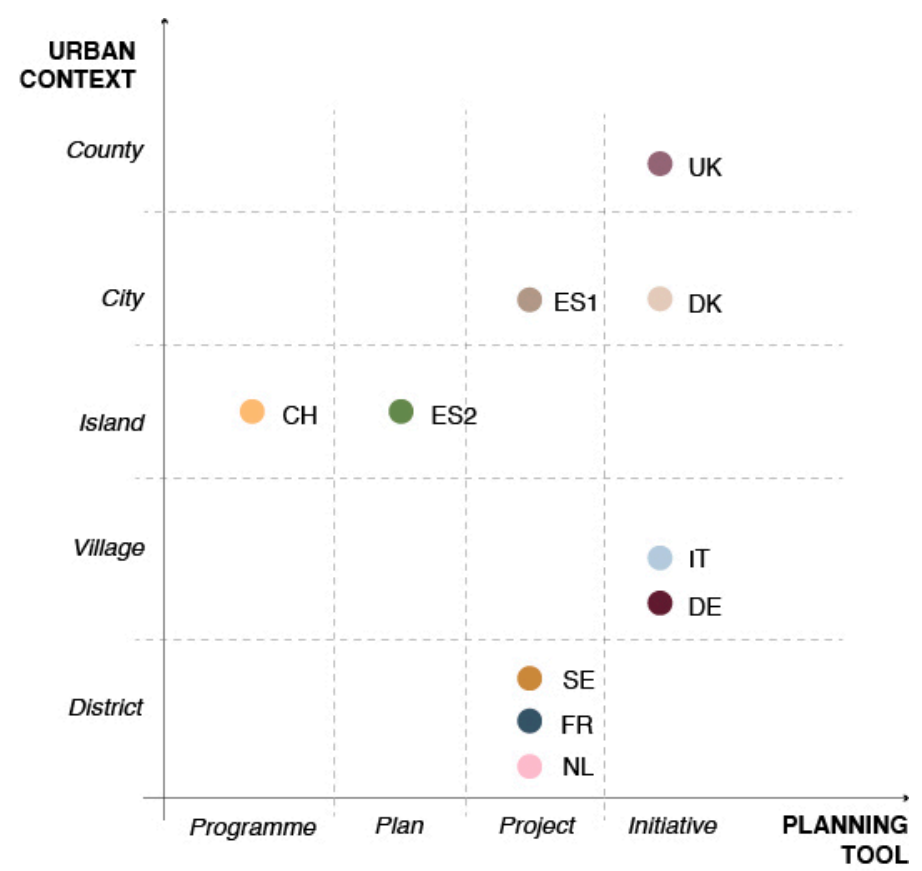

Figure 2. Case studies' classification and acronym in relation to the geographical scope and adopted tools (source: authors' own elaboration). 


\section{Results and Discussion}

In the following sub-sections, we discuss the main results of the analysis of the case studies on the basis of the three research questions around which the paper is pivoted: (i) What are the implemented actions in terms of energy production and efficiency measures? (ii) What are the legal framework and the origin of the funding within which the experiences develop? (iii) What are the number and types of involved actors and what partnerships link them? The discussion is further framed by considerations deriving from the comparison of the case studies' results (Table 2), in relation to three main factors: (i) the territorial scale they focus on, (ii) the planning tool they adopt and (iii) the main issue they deal with. 
Table 2. Case study and corresponding discussion elements: (1) type of local energy production and energy saving, (2) legal framework and origins of funding and (3)

the number of actors and type of contracts (source: authors' own elaboration).

\begin{tabular}{|c|c|c|c|c|c|c|}
\hline Case Study & Local Energy Production & Energy Saving & Legal Framework & $\begin{array}{l}\text { Origin of the } \\
\text { Funding }\end{array}$ & Actors Involved & Contracts \\
\hline $\begin{array}{l}\text { SE (Stockholm, } \\
\text { Sweden) }\end{array}$ & Solar photovoltaic & $\begin{array}{l}\text { Renovation of existing } \\
\text { buildings, slow mobilities, } \\
\text { shared mobility, behavior } \\
\text { program. }\end{array}$ & $\begin{array}{l}\text { Local energy } \\
\text { transition policy, } \\
\text { national and regional } \\
\text { legislation }\end{array}$ & $\begin{array}{l}\text { Citizens' investment, } \\
\text { municipal authority's } \\
\text { funding, local energy } \\
\text { operator, real estate } \\
\text { company } \\
\text { investments. }\end{array}$ & $\begin{array}{l}1 \text { public housing, } 1 \text { local } \\
\text { authority, police authority, } \\
\text { several businesses and } \\
\text { associations, citizens. }\end{array}$ & $\begin{array}{l}\text { Public-public } \\
\text { partnership }\end{array}$ \\
\hline $\begin{array}{l}\text { DK } \\
\text { (Samsø, Denmark) }\end{array}$ & $\begin{array}{l}\text { Wind, solar } \\
\text { thermal/photovoltaic, biomass }\end{array}$ & $\begin{array}{l}\text { Renovation of } 200 \text { existing } \\
\text { houses, sensing processes } \\
\text { and open meetings }\end{array}$ & $\begin{array}{l}\text { National legislation, } \\
\text { local energy } \\
\text { transition policy }\end{array}$ & $\begin{array}{l}\text { National, regional, } \\
\text { municipal, citizens } \\
\text { investments }\end{array}$ & $\begin{array}{l}1 \text { local authority, } 1 \text { farmer union, } \\
450 \text { citizens, } 1 \text { grassroots } \\
\text { organization }\end{array}$ & Residents' agreement \\
\hline $\begin{array}{l}\text { UK } \\
\text { (Cumbria, UK) }\end{array}$ & $\begin{array}{l}\text { Wind turbines/wind power } \\
\text { station }\end{array}$ & None & National legislation & Citizens investments & $\begin{array}{l}1 \text { national authority, } 1 \\
\text { cooperative, citizens. }\end{array}$ & $\begin{array}{l}\text { Private-private } \\
\text { partnership }\end{array}$ \\
\hline $\begin{array}{l}\text { NL } \\
\text { (Culemborg, The } \\
\text { Netherlands) }\end{array}$ & $\begin{array}{l}\text { Power and heat generation } \\
\text { from waste and sewage, small } \\
\text { wind turbines }\end{array}$ & $\begin{array}{l}\text { Closed water circuit, water } \\
\text { management system, organic } \\
\text { food production }\end{array}$ & $\begin{array}{l}\text { Local urban } \\
\text { development plan, } \\
\text { national legislation }\end{array}$ & $\begin{array}{l}\text { Municipal, } \\
\text { foundation } \\
\text { investments }\end{array}$ & $\begin{array}{l}1 \text { national authority, } 1 \text { local } \\
\text { authority, } 1 \text { foundation, } \\
\text { professionals; future inhabitants }\end{array}$ & Residents' agreement \\
\hline $\begin{array}{l}\text { DE } \\
\text { (Jühnde, Germany) }\end{array}$ & $\begin{array}{l}\text { Bioenergy plant running on } \\
\text { biogas and woodchip to supply } \\
\text { heat and power to the village }\end{array}$ & District heating network & National legislation & $\begin{array}{l}\text { National, citizens } \\
\text { investments }\end{array}$ & $\begin{array}{l}1 \text { local authority, } 1 \text { cooperative } \\
\text { association, } 1 \text { university }\end{array}$ & $\begin{array}{l}\text { Private-private } \\
\text { partnership }\end{array}$ \\
\hline $\begin{array}{l}\text { FR } \\
\text { (Lyon, France) }\end{array}$ & $\begin{array}{l}\text { Solar thermal/photovoltaic, } \\
\text { wood fuel boiler at block scale, } \\
\text { heat pumps and gas boiler }\end{array}$ & $\begin{array}{l}\text { Construction of new } \\
\text { buildings characterized by } \\
\text { passive solar design, envelop } \\
\text { insulation, heat recovery and } \\
\text { cross ventilation, light bulbs, } \\
\text { occupancy sensors }\end{array}$ & $\begin{array}{l}\text { Local urban } \\
\text { development plan, } \\
\text { national legislation, } \\
\text { European project. }\end{array}$ & European & $\begin{array}{l}1 \text { European authority, } 1 \text { local } \\
\text { authority, } 1 \text { local public company, } \\
1 \text { not for profit organization, } 1 \\
\text { local agency, } 1 \text { energy company, } \\
3 \text { real estate developers, } 1 \\
\text { research center. }\end{array}$ & $\begin{array}{l}\text { Public-private } \\
\text { partnership }\end{array}$ \\
\hline $\begin{array}{l}\mathrm{CH} \\
\text { (Zurich, Switzerland) }\end{array}$ & None & $\begin{array}{l}\text { Public transport, } \\
\text { pedestrian/cycle paths, } \\
\text { educational behavior } \\
\text { program, incentives to } \\
\text { electric cars/bikes }\end{array}$ & $\begin{array}{l}\text { Local urban traffic } \\
\text { policy }\end{array}$ & Municipal & $\begin{array}{l}1 \text { Canton, } 1 \text { national authority, } 1 \\
\text { local authority, transport } \\
\text { enterprises, } 1 \text { university, } 1 \text { car } \\
\text { group representing the interest of } \\
\text { car owners, } 1 \text { bike group, } 1 \\
\text { business community, } \\
\text { shopkeepers, municipalities, } \\
\text { associations. }\end{array}$ & $\begin{array}{l}\text { No formal } \\
\text { partnership }\end{array}$ \\
\hline $\begin{array}{l}\text { IT } \\
\text { (Peccioli, Italy) }\end{array}$ & $\begin{array}{l}\text { Cogeneration plant for energy } \\
\text { production from biogas, solar } \\
\text { photovoltaic and wind. }\end{array}$ & $\begin{array}{l}\text { Extension of the landfill of } \\
\text { waste disposal and the } \\
\text { construction of the } \\
\text { mechanical-biological } \\
\text { treatment plant. }\end{array}$ & National legislation & $\begin{array}{l}\text { Municipal, citizens' } \\
\text { investments. }\end{array}$ & $\begin{array}{l}1 \text { local authority, } 1 \text { public } \\
\text { company, citizens, } 1 \text { foundation. }\end{array}$ & $\begin{array}{l}\text { Agreement among } \\
\text { the involved actors }\end{array}$ \\
\hline
\end{tabular}


Table 2. Cont

\begin{tabular}{|c|c|c|c|c|c|c|}
\hline Case Study & Local Energy Production & Energy Saving & Legal Framework & $\begin{array}{l}\text { Origin of the } \\
\text { Funding }\end{array}$ & Actors Involved & Contracts \\
\hline $\begin{array}{l}\text { ES1 } \\
\text { (El Herrio, Spain) }\end{array}$ & $\begin{array}{l}\text { Wind/hydroelectric plant, solar } \\
\text { panel for public and private } \\
\text { buildings }\end{array}$ & $\begin{array}{l}\text { Incentives (subsidies) for } \\
\text { enhancing resident's mobility } \\
\text { with electric cars, public } \\
\text { lighting, electric plant, } \\
\text { education program. }\end{array}$ & $\begin{array}{l}\text { Local energy } \\
\text { transition plan, local } \\
\text { urban development } \\
\text { plan, European } \\
\text { program. }\end{array}$ & $\begin{array}{l}\text { National, regional, } \\
\text { citizens investments }\end{array}$ & $\begin{array}{l}1 \text { European authority, } 1 \text { national } \\
\text { authority, } 1 \text { regional authority, } 1 \\
\text { local authority, } 1 \text { energy } \\
\text { company; } 1 \text { national company, } 1 \\
\text { research center }\end{array}$ & $\begin{array}{l}\text { Public-private } \\
\text { partnership }\end{array}$ \\
\hline $\begin{array}{l}\text { ES2 } \\
\text { (Vitoria Gasteiz, } \\
\text { Spain) }\end{array}$ & None & $\begin{array}{l}\text { Car-free, pedestrian } \\
\text { areas/cycle paths, shared } \\
\text { mobility, construction of new } \\
\text { buildings, renovation of } \\
\text { existing buildings, urban } \\
\text { heating network. }\end{array}$ & Local mobility policy & Municipal & $\begin{array}{l}1 \text { local authority, } 1 \text { public agency, } \\
\text { citizens, } 1 \text { research center. }\end{array}$ & $\begin{array}{l}\text { Public-public } \\
\text { partnership }\end{array}$ \\
\hline
\end{tabular}




\subsection{Energy Production and Energy Efficiency Measures}

From a first comparison, the type of energy production and energy efficiency measures implemented in each case seems to be closely related to the main issue they deal with and the tool they adopt. For instance, GHG emissions reduction figures as a central issue in cities that are located in central-southern Europe. ES2 and $\mathrm{CH}$ aim at reducing $\mathrm{CO}_{2}$ emissions by working on existing mobility infrastructures and organizations. Both cases are characterized by interventions that reduce environmental negative impacts related to traffic and increase the accessibility of public spaces. On the other side, in northern Europe, main actions concern clean energy production sources (mostly wind power station and wind turbines but also biogas and biomass plants), generally implemented in small villages and rural areas whose economies are based on local agriculture and forestry (such as DE and DK). This may be related to institutional path-dependence, as northern countries have introduced carbon cabs and national subsidies for a long time and these measures are nowadays rather consolidated there [50-52].

When it comes to energy-saving measures, the analyzed interventions mainly include the promotion of buildings' retrofitting at the neighborhood or village scale, especially in northern countries. This might be related to the efforts that these contexts put in place through time with the aim of systematically intervening through dedicated policies and national programs [50]. Moreover, the intervention on existing buildings rather than new constructions might be related to the current extent of underused real estate assets in conjunction with zero population growth [43]. In this respect, southern contexts are characterized by more punctual and fragmented interventions for renovating the existing building stock. This situation may also be the consequence of contextual differences in relation to the propriety regime that, in southern European countries, is typically more fragmented if compared to the central and northern European states [51].

Interestingly, a number of districts interventions located in the north and in the center of Europe include a combination of energy-saving and clean production measures. This may derive from the provision of European incentives and promotion of local policies that favor the integration of multiple dimensions through a single intervention. To illustrate this, NL adopted from the very beginning an integrated approach that simultaneously considers the technological, environmental and behavioral dimensions of the renovation project at the neighborhood scale. This was favored by a specific Dutch policy introducing dedicated financial arrangements and by covenants agreements among relevant stakeholders [53]. As a consequence, the developers implement a mix of measures by installing wind turbines, disposing of solar panels for residential electricity production, making the water system delivery more efficient, enhancing the bike and pedestrian networks and involving the residents in different phases of the project.

On the contrary, two cases from Southern Europe show how interventions may also develop starting from a single dimension in the framework of wider planning and policy strategies. For instance, ES1 had a strong motivation in fostering a green economy, while preserving social development at the territorial scale. To do so, the project first saw the realization of a windpump hydropower station that takes into account the patrimonial importance of existing archaeological sites. and only later it included other actions, such as the enhancement of electric mobility via subsidies for residents or awareness campaigns and education activities about daily energy savings. As another example, IT disposed of wider open spaces that allowed the passage from an unmanaged landfill collecting waste from six municipalities in the area to the reclamation and expansion of the area, made available for a considerable part of the territory to the parallel improvement of the waste treatment and management systems.

\subsection{Legal Framework and Funding Sources}

The legal frameworks and the corresponding funding resources that characterize the analyzed cases study are strictly related to the territorial scale of the interventions and the type of tool adopted by the latter. Half of the selected experiences (distributed in the south, center and north of Europe) are framed in the context of the state legislation, that includes national acts that promote renewable energy 
sources (DE) or regulations that imposes minimum standards and requirements regarding energy consumptions of existing and new buildings (FR). In DE, the government promoted the development of clean energy supply by introducing in 2000 the Renewable Energy Sources Act (EEG), guaranteeing fixed tariffs for electricity and a bonus for heat utilization. Within this context, the village of Jhünde was considered as a pilot project to be replicated at a wider scale and, for this reason, it got funded by the German Federal Ministry of Food, Agriculture and Consumer Protection. Interestingly, FR clean energy production objectives were particularly ambitious when compared to the thermal regulation in place (RT2000), and the main results and lessons learnt form the experience partially contributed to the subsequent definition of new thermal regulation (RT2012) [54]. Moreover, it emerges that as many as six projects are framed in the local planning and policy visions, but regarding different kind of documents: DK, SE and ES1 projects concern local energy transition plans; $\mathrm{CH}$ and ES2 (both city-scale cases) feature local mobility plan; and NL and FR (focusing on the district scale) are both acting through urban development plans. In $\mathrm{CH}$, sustainable mobility strategies were implemented gradually from the 1970s till the present days and, only in recent times, these measures were framed within a local energy transition policy. This heterogeneity in terms of tools reflects the high heterogeneity that characterizes territorial governance and spatial planning systems in Europe, each with national (and often subnational) context that is characterized by a peculiar set of more or less binding strategies, policies and plans $[29,30]$.

All three cases located in northern Europe focus on new construction of clean energy production systems at the local level. This might be partially related to economic and legislative issues and, in particular, to the possibilities offered by European and national regulatory frameworks to offer public incentives to promote the implementation of clean energy production measures [52]. Similarly, the majority of the projects located in northern Europe are funded by a combination of public and private resources or by private resources only (such as DK or UK), while southern and central experiences tend to either be financed by the public sector or by a combination of public and private resources that features a prevalence of the former (such as DE or ES2). These different situations are partially explained by path-dependent logics concerning the role of citizens in the decision-making process behind energy policies and, more in general, the differential set of relations that links the state actors, the market actors and the civil society in different contexts [31].

More specifically, half of the selected cases (in north, center and south Europe) are partially funded by citizens' investments, meaning that households play an active role in the implementation of energy production and energy savings measures [52]. In some cases (as for DE, IT, DK), citizens generally act as private investors and own a share of the means of clean energy production together with other private or public actors. For example, in DK more than half (around 70\%) of the resources invested in the installation of wind turbines installation came from local investors. This was possible thanks to people's savings and island bank cooperativeness: special loan packages enabled to borrow money for buying shares in collaboratively owned technology. Interestingly, co-ownership business model was traditionally used in the Danish island of Samsø in the form of co-ownership of a slaughterhouse or handling berry for making jam, and local merchants had already gained some experience in the shared construction and operation of windmills. In other cases (NL and SE), citizens contributed to renovation works and gained economic benefits derived from them in the following years. For example, in SE, the tenants sign a contract to pay for electricity, water and waste collection as much as they do for the next 10-20 years. Renovation loans are then conducted and financed with decreased expenses thanks to energy efficiency interventions.

National authorities' funding were employed in only three cases distributed across Europe (ES1, $\mathrm{DE}$ and DK), and always in addition to other sources of funding. Interestingly, two of them (ES1 and DK) deal with insular areas and their main objective is to guarantee energy independence from the mainland: in ES1 the national authority allocated a considerable amount of economic resources that was enough to finance the development of a hydropower plant. This is related to the specific issue of energy self-sufficiency and the economic repercussions that an insular context might determine on 
the mainland on which it depends [55]. Very few cases (located in the center and south of Europe) are exclusively funded by the municipal authorities and they mostly include energy-saving measures, working on sustainable mobility and insulation of public buildings (ES2 and $\mathrm{CH}$ ). This is the case of ES2, where the adopted measures include car-free new pedestrian areas, the promotion of non-motorized transport and the improvement of existing bike-lane networks, and $\mathrm{CH}$, that concentrates its resources on the upgrading and attractiveness of public transport to foster a decrease motorized private transport.

\subsection{Involved Actors and Partnerships}

The involved actors and the adopted partnerships in the various cases are strongly related to the scale of intervention and the main issue at stake. The majority of the cases work at the district scale, and they are mostly located in the central and northern part of Europe (FR, NL, SE), and at the scale of villages, mainly in the central-southern part of Europe (IT, ES1, DE). This might be related to the variety of territorial governance contexts and the complexity of coordination in the overlap between different institutional and regulatory levels [16]. Moreover, all the investigated experiences are characterized by the involvement of private actors (energy companies, foundations), public institutions (local, national and European) and the third sector (associations, NGOs, cooperatives). Interestingly, the majority of central and northern cases include at least one private actor that is either an energy company (such as FR) - acting as the main clean energy supplier or as the main service provider for that context-or an energy cooperative association (UK and DE)—where residents are often founding members and act as main shareholders. For example, the German initiative DE saw the foundation of a cooperative that involved a high share of the village population with the aim of acquiring the necessary investment subsidies. This might be related to the access conditions to public subsidies for energy-related interventions [50].

The promoters of central and southern experiences are both private (a company) and public (a political leader), while in the northern part of Europe they mostly belong to the private realm. These different situations are partially explained by the role of citizens and its degree of influence at different timings in the decision-making process [52]. For example, in IT (and similarly to DE) the Major and a group of people in the city council had, from the very beginning, an active role in promoting the project and motivating the inhabitants to support it. On the contrary, in NL, the municipalities took part in the project only after two years since the promotion of the initiative. More specifically, in the Italian case, the municipality promoted the foundation of a public company, open to citizens, that economically support the project of waste land extension and a new management system. In the Dutch case, the idea was initially developed by a group of scientists with different backgrounds, who initiated a private foundation and rapidly engaged a network of future possible inhabitants, that was since then involved in the conception and design of the project. Table 2 shows that half the selected cases, mostly located in southern and central Europe, include one or more educational institutions or research centres (ES1, DE, CH, FR and ES2), that contribute to enhance the innovative character of the adopted solutions and partially testify the experimental character of energy-related intervention in urban planning. For example, in ES1 the Canary Island's Institute of Technology was involved from the beginning, with the main aim of developing of alternative models and technologies for energy generation on the island.

The majority of cases include a formal partnership among the involved actors that might vary from private-private to a public-private, to a public-public contract. The first type of partnership is common in the central and northern European cases, especially for projects based on a cooperative business model for clean energy production (such as UK). The public-private partnership concerns projects that are located in central and southern Europe where both energy-saving and production measures are involved (such as ES1 and FR). Public-private partnership often includes the participation of private companies (such as the Energy Service Companies-ESCo), which undertake the design and the financing of energy retrofitting works, and the building's owners, who are committed to paying the private company a fee commensurate with the actual achievement of the energy performance. 
The public-public contract occurs in north, center and south Europe, in cases dealing with projects where the greater part of the interventions concerned energy-savings measures (see Section 5.1). Informal agreements characterize older experiences that included an initially limited number of actors. This is the case of DK, started at the end of 90 s, where the main actors are represented by a local energy development company as promoter of the initiative, the island's inhabitants as main investors and a grassroots organization on behalf of the general island public.

\section{Concluding Remarks and Future Research Perspectives}

The contribution presented and discussed the results of the analysis of 10 case studies from various European countries, representing as many experiences somehow anticipating a transition of local communities towards a low-carbon society. Whereas the proposed research certainly features some limitations, which are further detailed below in the text, the authors hope it will also constitute an inspiration for future research perspectives concerning the governance of low-carbon transition in the European context and beyond. The experiences under investigation differ in their geographical positions, urban characteristics and socio-political contexts. Still, they raise several transversal issues, concerning the typology and the combination of the implemented interventions, the origin of funding and the legal framework in which they are eventually integrated and the type and number of actors involved in the process.

The survey allows us to understand some contextual aspects in dealing with the governance of low-carbon transition in Europe that are mainly addressed to three main factors (i) the geographical location and urban features of the territories where projects have developed, (ii) their institutional and political settings and (iii) the economic and financial contexts in which they are framed. Firstly, urban and geographical conditions are showed to partially influence the type and number of energy production and saving interventions. This suggests the need of rethinking the scales of different measures in an integrated and dynamic manner that takes into consideration the variegated distribution of human capital and natural resources on territories. Secondly, many projects tend to be eradicated from a long-standing institutional and political culture in which legal framework and dedicated funding allocation didn't occur simultaneously with the effective implementation of projects' interventions. In addition to this, the lack of sufficient local economic resources contributes to the tendency of searching for synergies, in terms of municipalities' interests and economic resources, among different governance levels that might also favour local attractiveness. Thirdly, new partnerships and network relations are built among state and non-state actors, going in the direction of a renovation of consolidated decision-making practices and a new role of private actors and third parties in contributing to energy policies. In this prospect, the variety of ownership assets and the perspective of a return on investments might influence the number and type of involved actors.

Overall, the number of cases considered in the present study certainly limit the possibility of generalization of the identified results. In this light, these results should be deepened and further consolidated through a more systematic collection and analysis of local experiences located throughout Europe. However, the positive outcomes of the analyzed interventions, presented in relation to the governance contexts within which they were conceived, developed and implemented, provides interesting inputs concerning the actual possibility to learn from these interventions and to stimulate the undertaking of similar experiences in other contexts, or even to consider their possible upscaling through specifically dedicated national and EU policies [33]. Finally, the results of this paper will contribute to the LOTUS project and the development of Management UrbEM serious game (see Section 3), that will provide further inputs through its simulation of the decision-making arena in dealing with the variety of involved actors, the adopted partnership models and the available funding in the low-carbon transition of cities. 
Author Contributions: Conceptualization, F.R., F.A., G.C. and I.M.L.; methodology, F.R., F.A., G.C. and I.M.L.; formal analysis, F.R.; investigation, F.R., F.A., G.C. and I.M.L.; resources, F.R., F.A., G.C. and I.M.L.; data curation, F.R., F.A., G.C. and I.M.L.; writing-original draft preparation, F.R.; writing-review and editing, F.R., F.A., G.C. and I.M.L.; visualization, F.R.; supervision, G.C. and I.M.L.; project administration, I.M.L.; funding acquisition, I.M.L. All authors have read and agreed to the published version of the manuscript.

Funding: This article has been subsidized by the project LOTUS (Locally Organized Transition of Urban Sustainable Spaces) that informed the present work. Lotus is funded by ERASMUS+ Strategic Partnership for Higher Education, Call 2019 Round 1 KA2-Cooperation for innovation and the exchange of good practices, contract number 870697. Project's partners include Hochschule Fur Öffentliche Verwaltung Kehl (Germany), Logiville (France), Zapadoceska Univerzita V Plzni (Czech Republic), Politecnico di Torino (Italy), Rigas Tehniska Universitate (Latvia), Université Paris-Est Marne la Vallée (France). Project start date: 01/09/2019. Project Duration: 36 months.

Conflicts of Interest: The authors declare no conflict of interest. The funders had no role in the design of the study; in the collection, analyses, or interpretation of data; in the writing of the manuscript, or in the decision to publish the results.

\section{References}

1. Cotella, G.; Crivello, S.; Karatayev, M. European Union Energy Policy Evolutionary Patterns. In Low-carbon Energy Security from a European Perspective; Elsevier BV: Amsterdam, The Netherlands, 2016; pp. $13-42$.

2. Decision No 406/2009/EC of the European Parliament and of the Council of 23 April 2009 on the Effort of Member States to Reduce Their Greenhouse Gas Emissions to Meet the Community's Greenhouse Gas Emission Reduction Commitments up to 2020. Available online: https:/ec.europa.eu/clima/policies/ strategies/2020_en\#tab-0-1 (accessed on 14 September 2020).

3. European Commission. Communication from the Commission to the European Parliament, the Council, the European Economic and Social Committee and the Committee of the Regions A Policy Framework for Climate and Energy in the Period from 2020 to 2030. 2014. Available online: https://eur-lex.europa.eu/legalcontent/EN/TXT/?uri=CELEX:52014DC0015 (accessed on 14 September 2020).

4. European Commission. Communication from the Commission to the European Parliament, the Council, the European Economic and Social Committee and the Committee of the Regions and the European Investment Bank, A Clean Planet for all A European Strategic Long-Term Vision for a Prosperous, Modern, Competitive and Climate Neutral Economy. 2018. Available online: https:/eur-lex.europa.eu/legal-content/EN/ALL/ ?uri=CELEX:52018DC0773 (accessed on 14 September 2020).

5. EIA Report. Energy Technology Perspectives 2016, Flagship Report. 2016. Available online: https: //www.iea.org/reports/energy-technology-perspectives-2016 (accessed on 14 September 2020).

6. Bottero, M.; Caprioli, C.; Cotella, G.; Santangelo, M. Sustainable Cities: A Reflection on Potentialities and Limits based on Existing Eco-Districts in Europe. Sustainability 2019, 11, 5794. [CrossRef]

7. Luque-Ayala, A.; Marvin, S.; Bulkeley, H. Rethinking Urban Transitions: Politics in the Low Carbon City; Routledge: Abingdon, UK, 2018. [CrossRef]

8. Bulkeley, H. Cities and the Governing of Climate Change. Annu. Rev. Environ. Resour. 2010, 35, $229-253$. [CrossRef]

9. Salvia, G.; Morello, E.; Rotondo, F.; Sangalli, A.; Causone, F.; Erba, S.; Pagliano, L. Performance Gap and Occupant Behavior in Building Retrofit: Focus on Dynamics of Change and Continuity in the Practice of Indoor Heating. Sustainability 2020, 12, 5820. [CrossRef]

10. Collier, U. Local authorities and climate protection in the European Union: Putting subsidiarity into practice? Local Environ. 1997, 2, 39-57. [CrossRef]

11. Lombardi, P.; Gruenig, M. Low-Carbon Energy Security from A European Perspective; Elsevier: London, UK, 2016.

12. Abastante, F.; Lami, I.M.; Lombardi, P.; Toniolo, J. District energy choices: More than a monetary problem a SDSS approach to define urban energy scenarios. Valori E Valutazioni 2019, 22, 109-120.

13. Sonetti, G.; Arrobbio, O.; Lombardi, P.; Lami, I.M.; Monaci, S. “Only Social Scientists Laughed”: Reflections on Social Sciences and Humanities Integration in European Energy Projects. Energy Res. Soc. Sci. 2020, 61, 101342. [CrossRef]

14. Cassen, C.; Hamdi-Chérif, M.; Cotella, G.; Toniolo, J.; Lombardi, P.; Hourcade, J.-C. Low Carbon Scenarios for Europe: An Evaluation of Upscaling Low Carbon Experiments. Sustainability 2018, 10, 848. [CrossRef] 
15. Abastante, F.; Lami, I.M.; Lombardi, P. An integrated participative spatial decision support system for smart energy urban scenarios: A financial and economic approach. Buildings 2017, 7, 103. [CrossRef]

16. Valkenburg, G.; Cotella, G. Governance of energy transitions: About inclusion and closure in complex sociotechnical problems. Energ Sustain. Soc. 2016, 6, 20. [CrossRef]

17. EEA Report. Sustainability Transitions: Policy and Practice; European Environment Agency, No 09/2019; European Environment Agency: Copenhagen, Denmark, 2019.

18. Hodson, M.; Marvin, S.; Bulkeley, H. The Intermediary Organisation of Low Carbon Cities: A Comparative Analysis of Transitions in Greater London and Greater Manchester. Urban Stud. 2013, 50, 1403-1422. [CrossRef]

19. Solly, A.; Berisha, E.; Cotella, G.; Janin Rivolin, U. How Sustainable Are Land Use Tools? A Europe-Wide Typological Investigation. Sustainability 2020, 12, 1257. [CrossRef]

20. Lotus-Transition. Available online: https://lotus-transition.eu/ (accessed on 15 March 2020).

21. Waas, T.; Hugé, J.; Verbruggen, A.; Wright, T. Sustainable Development: A Bird's Eye View. Sustainability 2011, 3, 1637-1661. [CrossRef]

22. Cumo, F.; Garcia, D.A.; Calcagnini, L.; Rosa, F.; Sferra, A.S. Urban policies and sustainable energy management. Sustain. Cities Soc. 2012, 4, 29-34. [CrossRef]

23. Cotella, G. The Urban Dimension of EU Cohesion Policy. Landsc. Paradig. Post-Urban Spaces 2018, 175, 133-151. [CrossRef]

24. Nagorny-Koring, N.C.; Nochta, T. Managing urban transitions in theory and practice-The case of the Pioneer Cities and Transition Cities projects. J. Clean. Prod. 2018, 175, 60-69. [CrossRef]

25. Geels, F.W. A socio-technical analysis of low-carbon transitions: Introducing the multi-level perspective into transport studies. J. Transp. Geogr. 2012, 24, 471-482. [CrossRef]

26. Kivimaa, P.; Hyysalo, P.; Boon, W.; Klerkx, L.; Martiskainen, M.; Schot, P. Passing the baton: How intermediaries advance sustainability transitions in different phases. Environ. Innov. Soc. Transit. 2019, 31, 110-125. [CrossRef]

27. Warbroek, B.; Hoppe, T.; Coenen, F.; Bressers, H. The Role of Intermediaries in Supporting Local Low-Carbon Energy Initiatives. Sustainability 2018, 10, 2450. [CrossRef]

28. Geels, F.W.; Berkhout, F.; Van Vuuren, D. Bridging analytical approaches for low-carbon transitions. Nat. Clim. Chang. 2016, 6, 576-583. [CrossRef]

29. Nadin, V.; Stead, D. European Spatial Planning Systems. Soc. Models Learn. 2008, 44, 35-47. [CrossRef]

30. Nadin, V.; Fernández Maldonado, A.M.; Zonneveld, W.; Stead, D.; Dąbrowski, M.; Piskorek, K.; Rivolin, U.J. COMPASS-Comparative Analysis of Territorial Governance and Spatial Planning Systems in Europe; Final Report; ESPON EGTC: Luxemburg, 2018.

31. Berisha, E.; Cotella, G.; Janin Rivolin, U.; Solly, A. Spatial governance and planning systems and the public control of spatial development: A European typology. Eur. Plan. Stud. 2020, 46, 1-20. [CrossRef]

32. Mouaheb, H.; Fahli, A.; Moussetad, M.; Eljamali, S. The Serious Game: What Educational Benefits? Procedia Soc. Behav. Sci. 2012, 46, 5502-5508. [CrossRef]

33. Cotella, G.; Janin Rivolin, U.; Santangelo, M. Transferring 'good' territorial governance across Europe: Opportunities and barriers. In Territorial Governance across Europe: Pathways, Practices and Prospects; Schmitt, P., Van Well, L., Eds.; Routledge: New York, NY, USA, 2015. [CrossRef]

34. Vilmin, T. Urbax, Une Simulation Jouée de l'Aménagement Urbain, Journée d'études Des Serious Game Pour l'Apprentissage de la Production de Projets Urbains, Organisée par Nathalie Molines et Carine Henriot, Compiégne. 2018. Available online: https://calenda.org/492459?file=1 (accessed on 15 March 2020).

35. Pojani, D.; Rocco, R. Edutainment: Role-Playing versus Serious Gaming in Planning Education. J. Plan. Educ. Res. 2020. [CrossRef]

36. Tzeiranaki, S.T.; Bertoldi, P.; Paci, D.; Castellazzi, L.; Serrenho, T.R.; Economidou, M.; Zangheri, P. Energy Consumption and Energy Efficiency Trends in the EU-28, 2000-2018; EUR 30328 EN; Publications Office of the European Union: Luxembourg, 2020. [CrossRef]

37. Rhodes, R.A.W. Understanding Governance: Ten Years On. Organ. Stud. 2007, 28, 1243-1264. [CrossRef]

38. Iuel-Stissing, J.; Pallesen, T.; Karnøe, P.; Jacobsen, P.H. Governing system transitions in the context of scattered agency: Flexibility, action, and ecologies of epistemic equipment. Energy Res. Soc. Sci 2020, 69, 101730. [CrossRef] 
39. Köhler, J.; Geels, F.W.; Kern, F.; Markard, J.; Onsongo, E.; Wieczorek, A.; Alkemadee, F.; Avelinof, F.; Bergekg, A.; Boons, F.; et al. An agenda for sustainability transitions research: State of the art and future directions. Environ. Innov. Soc. Transit. 2019, 31, 1-32. [CrossRef]

40. Hoppe, T.; van Bueren, E. Guest editorial: Governing the challenges of climate change and energy transition in cities. Energ Sustain. Soc. 2015, 5, 19. [CrossRef]

41. Thomann, E.; Maggetti, M. Designing Research with Qualitative Comparative Analysis (QCA): Approaches, Challenges, and Tools. Soc. Methods Res. 2020, 49, 356-386. [CrossRef]

42. Garibaldi, J.A.; Winkler, H.; La Rovere, E.L.; Cadena, A.; Palma, R.; Sanhueza, J.E.; Tyler, E.; Gunfaus, M.T. Comparative analysis of five case studies: Commonalities and differences in approaches to mitigation actions in five developing countries. Clim. Dev. 2013, 6, 59-70. [CrossRef]

43. Lami, I.M. Shapes, Rules and Value. In Abandoned Buildings in Contemporary Cities: Smart Conditions for Actions; Lami, I.M., Ed.; Springer International Publishing: Cham, Switzerland, 2020; pp. 149-162. [CrossRef]

44. Cordis.europa.eu. Available online: https://cordis.europa.eu/project/id/320169/reporting (accessed on 15 March 2020).

45. Local-Social-Innovation. Available online: https://local-social-innovation.eu/ (accessed on 15 March 2020).

46. Caiati, G.; Quinti, G.M.; Kazakopoulos, P.; Sitko, I. MILESECURE-2050 D2.1—Report on Integrated Analysis of Local Anticipatory Experiences in Energy Transition in Europe, WP2; Analysis of Concrete Anticipatory Experiences on Energy Transition at the Local Level. Available online: https://cordis.europa.eu/project/id/ 320169/reporting (accessed on 15 May 2020).

47. Caiati, G.; Marta, F.L.; Quinti, G.M. D3.1—Report about Profiles of Social Innovation "in Action" for each Cluster, WP3 Clusters of Case Studies of Social Innovation. 2019. Available online: https://local-socialinnovation.eu/fileadmin/user_upload/Deliverables/SMARTEES-D3.1_SI_in_Action_R1.pdf (accessed on 15 May 2020).

48. Abastante, F.; Lami, I.M.; Mecca, B. Performance Indicators Framework to Analyse Factors Influencing the Success of Six Urban Cultural Regeneration Cases. In New Metropolitan Perspectives. NMP 2020. Smart Innovation, Systems and Technologies; Bevilacqua, C., Calabrò, F., Della Spina, L., Eds.; Springer: Cham, Switzerland, 2020; Volume 178. [CrossRef]

49. Lami, I.L.; Moroni, S. How Can I Help You? Questioning the Role of Evaluation Techniques in Democratic Decision-Making Processes. Sustainability 2020, 12, 8568. [CrossRef]

50. EEA Signals. Shaping the Future of Energy in Europe: Clean, Smart and Renewable; European Environment Agency: Copenhagen, Denmark, 2017.

51. Economidou, M.; Todeschi, V.; Bertoldi, P. Accelerating Energy Renovation Investments in Buildings—Financial $\mathcal{E}$ Fiscal Instruments across the EU, EUR 29890 EN; Publications Office of the European Union: Luxembourg, 2019. [CrossRef]

52. EEA Report. Renewable Energy in Europe 2017. Recent Growth and Knock-on Effects; European Environment Agency: Copenhagen, Denmark, 2017.

53. Melchert, L. The Dutch sustainable building policy: A model for developing countries? Build. Environ. 2007, 42, 893-901. [CrossRef]

54. Koch-Mathian, S. CONCERTO INITIATIVE RENAISSANCE, Renewable Energy Acting in SuStainable And Novel Community Enterprises. Available online: http://www.renaissance-project.eu/IMG/pdf/Final_ _activity_report_comp.pdf (accessed on 15 May 2020).

55. Tsagkari, M.; Jusmet, J.R. Renewable Energy Projects on Isolated Islands in Europe: A Policy Review. Int. J. Energy Econ. Policy 2020, 10, 21-30. [CrossRef]

Publisher's Note: MDPI stays neutral with regard to jurisdictional claims in published maps and institutional affiliations.

(C) 2020 by the authors. Licensee MDPI, Basel, Switzerland. This article is an open access article distributed under the terms and conditions of the Creative Commons Attribution (CC BY) license (http://creativecommons.org/licenses/by/4.0/). 